\title{
Antibacterial constituents of Neohyptis paniculata
}

\section{Mukhlesur Rahman ${ }^{\mathrm{a}, \mathrm{b},{ }^{*}}$ and Simon Gibbons ${ }^{\mathrm{a}}$}

${ }^{a}$ Department of Pharmaceutical and Biological Chemistry, UCL School of Pharmacy, 29-39 Brunswick Square, London WC1N 1AX, UK

${ }^{b}$ Medicine Research Group, School of Health, Sport and Bioscience, University of East London, Stratford Campus, Water Lane, London E15 4LZ, UK

Correspondence

Present address: Medicine Research Group, School of Health, Sport and Bioscience, University of East London, Stratford Campus, Water Lane, London E15 4LZ, UK Tel: +44-2082234299; e-mail: m.rahman@uel.ac.uk (M.M. Rahman) 
Graphical Abstract

Antibacterial constituents of Neohyptis paniculata

M. Mukhlesur Rahman* and Simon Gibbons

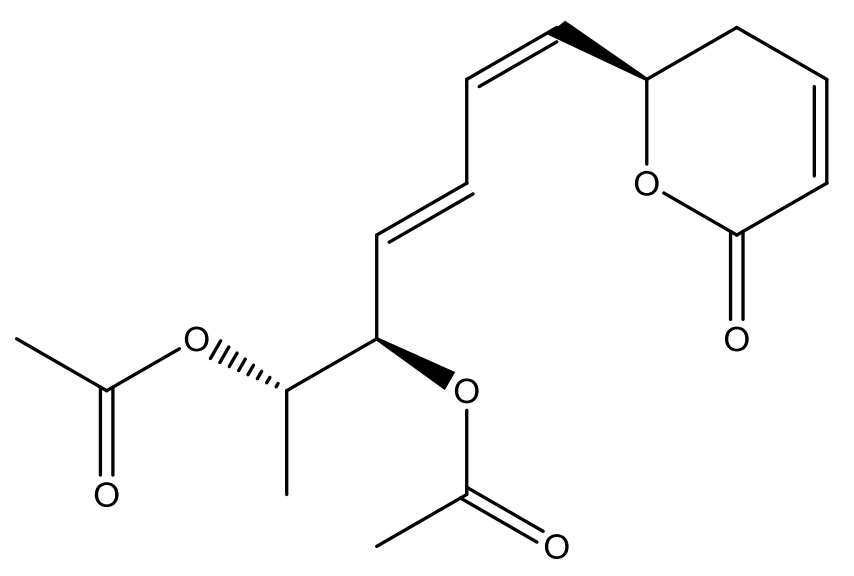


Abstract

A new $\alpha$-pyrone, $6 R$-[5R,6S-diacetyloxy-1Z,3E-heptadienyl]-5,6-dihydro-2Hpyran-2one (1), along with six known compounds including an $\alpha$-pyrone, flavones and terpenes was isolated from the aerial parts of Neohyptis paniculata. The structure of 1 was established unambiguously by MS and a series of 1D and 2D-NMR spectroscopic analyses. The antibacterial activity of the compounds (1-7) was investigated against five strains of multi-drug resistant (MDR) and methicillinresistant Staphylococcus aureus and minimum inhibitory concentrations (MICs) of these compounds were found to be in the range of $64-256 \mu \mathrm{g} / \mathrm{mL}$.

\section{Keywords}

Neohyptis paniculata, Lamiaceae, $\quad \alpha$-pyrone, $\quad 6 R$-[5R,6S-diacetyloxy-1Z,3Eheptadienyl]-5,6-dihydro-2H-pyran-2one, Antibacterial, Staphylococcus aureus. 


\section{Introduction}

Neohyptis paniculata (Bak.) J. K. (Lamiaceae), a slender and erect perennial herb attaining a height of 1-3 ft., is a monotypic species that is characterized by a small and white corolla with purple dots. The plant grows well in savanna swamps of some African countries including Ghana, Guinea, Angola, Cameroon, Angola and SierraLeone [1]. This species has not been previously investigated for phytochemistry and bioactivity.

Infections caused by multidrug-resistant (MDR) and methicillin-resistant strains of Staphylococcus aureus (MRSA) are still problematic in the clinical environment and the need for new antibacterials is becoming increasingly urgent. As part of an ongoing effort to characterize new compounds from species of Lamiaceae $[2,3]$ with antibacterial activity against multidrug-resistant (MDR) strains of Staphylococcus aureus, we here report the isolation of a new compound (1) together with six known compounds including an $\alpha$-pyrone, flavones and terpenes from the aerial parts of $N$. paniculata and the antibacterial activities of compounds 1-7 against five bacterial strains of MDR and methicillin-resistant Staphylococcus aureus.

\section{Materials and Methods}

\subsection{General.}

Optical rotations were measured on a Perkin Elmer Polarimeter 341. IR spectra were recorded as a dry film on a Perkin Elmer Spectrum 1000 FT-IR spectrometer. UV spectra were obtained on a Unicam UV 4-100 UV/vi spectrophotometer in MeOH. HREIMS were recorded on a Micromass Q-TOF Global Tandem Mass Spectrometer. NMR spectra (both 1D and 2D) were obtained on a Bruker AVANCE 500 spectrometer $\left(500 \mathrm{MHz}\right.$ for ${ }^{1} \mathrm{H}$ and $125 \mathrm{MHz}$ for $\left.{ }^{13} \mathrm{C}\right)$, using the residual solvent peaks as internal standard. Vacuum-liquid chromatography (VLC) was carried out 
using Merck Si gel $60 \mathrm{H}$. Gel filtration was performed using Sephadex LH-20 (Sigma). TLC and PTLC were conducted on normal-phase Merck Si gel $60 \mathrm{PF}_{254}$ and reverse-phase Merck Si gel RP-18 $\mathrm{PF}_{254}$ plates $(20 \mathrm{~cm} \mathrm{X} 20 \mathrm{~cm})$. Spots on TLC and PTLC plates were visualised under UV light (254 and $366 \mathrm{~nm})$ and spraying with $1 \%$ vanillin- $\mathrm{H}_{2} \mathrm{SO}_{4}$ followed by heating at $110^{\circ} \mathrm{C}$ for $5-10 \mathrm{~min}$.

\subsection{Plant material}

The aerial parts of $N$. paniculata were collected from Ghana in 2006. A herbarium specimen of this collection is maintained at the UCL School of Pharmacy, University of London, UK.

\subsection{Extraction and isolation}

$250 \mathrm{~g}$ of dried, ground plant material was sequentially extracted with hexane, $\mathrm{CHCl}_{3}$ and methanol in a Soxhlet apparatus. This sequential extraction with solvents of increasing polarity allowed preliminary separation of the components based on the polarity of the metabolites. As both hexane and chloroform extracts showed antibacterial activity, these two extracts were analysed further for the isolation and purification of compounds.

The hexane extract $(900 \mathrm{mg})$ was subjected to gel filtration over Sephadex LH20 (27 g) using a mobile phase of hexane, $\mathrm{CHCl}_{3}$ and $\mathrm{MeOH}$ in a ratio of 2:5:1 to obtain a total of 8 fractions (50 mL each fraction). Solid phase extraction (SPE) (Si 60G; mobile phase $100 \%$ hexane to $100 \%$ EtOAc) on fraction $2(200 \mathrm{mg})$ was carried out using hexane and EtOAc in a mixture of increasing polarity collecting $50 \mathrm{~mL}$ of each eluent. Preparative TLC (Si gel $60 \mathrm{PF}_{254} ; 100 \%$ hexane) on the SPE sub-fraction eluted with $100 \%$ hexane afforded $\mathbf{2}(2.2 \mathrm{mg})$ and $\mathbf{3}(3.1 \mathrm{mg})$ while compounds $\mathbf{1}$ (2.5 $\mathrm{mg})$ and $4(10.6 \mathrm{mg})$ were isolated from the SPE sub-fraction eluted with 50\% EtOAc in hexane followed by preparative-TLC (Merck Si gel RP-18 $\mathrm{PF}_{254} ; \mathrm{MeOH}: \mathrm{H}_{2} \mathrm{O}$ : 
$\mathrm{AcOH}=59: 40: 1)$. Further, preparative TLC $\left(\mathrm{Si}\right.$ gel $60 \mathrm{PF}_{254} ; 15 \%$ EtOAc in toluene plus 3-4 drops of $\mathrm{AcOH}$ ) on the SPE sub-fraction eluted with 10-20\% EtOAc hexane led to the isolation of $5(4.1 \mathrm{mg})$ and $7(6.3 \mathrm{mg})$.

The $\mathrm{CHCl}_{3}$ extract $(5.5 \mathrm{~g})$ was fractionated by VLC over Si gel $60 \mathrm{H}$ using hexane-EtOAc and EtOAc-MeOH mixtures of increasing polarity. The eluates were combined together on the basis of TLC analysis. VLC fractions eluted with $20-25 \%$ EtOAc in petroleum ether were further subjected to preparative-TLC to yield 5 (14.5 $\mathrm{mg}$ ) and $6(16.6 \mathrm{mg})$. Gel filtration over Sephadex LH20 (hexane: $\mathrm{CHCl}_{3}: \mathrm{MeOH}=$ 2:5:1) on the VLC fractions eluting with $40-50 \%$ EtOAc in hexane gave $15.4 \mathrm{mg}$ of 7 . 2.4. $6 R$-[5R,6S-diacetyloxy-1Z,3E-heptadienyl]-5,6-dihydro-2H-pyran-2one (1)

White gum. $[\alpha]_{D}^{20}-30.1\left(\mathrm{CHCl}_{3} ; \mathrm{c} 4.55\right)$. UV $\lambda_{\max }^{\mathrm{MeOH}} \mathrm{nm}(\log \varepsilon): 229$ (4.26). IR (solution in $\mathrm{CHCl}_{3}$ ) $\vee \mathrm{cm}^{-1}$ : 1736, 1360, 1225, 1070, 1025, 955, 800; ${ }^{1} \mathrm{H}$ NMR, ${ }^{13} \mathrm{C}$ NMR and HMBC, see Table 2. HRMS $m / z[\mathrm{M}+\mathrm{Na}$ ] peak at $m / z 331.1157$ (Calcd. $331.1163)$.

\subsection{Bacterial strains}

A standard S. aureus strain ATCC 25923 and a clinical isolate (XU212), which possesses the TetK efflux pump and is also an MRSA strain, were obtained from E. Udo [4]. Strain RN4220 which has the MsrA macrolide efflux pump was provided by J. Cove [5]. EMRSA-15 [6] was obtained from Dr Paul Stapleton, UCL. Strain SA1199B which over-expresses the NorA MDR efflux pump was the gift of Professor Glenn Kaatz [7]. Norfloxacin was obtained from the Sigma Chemical Co.

\subsection{Antibacterial assay}

Overnight cultures of each strain were made up in $0.9 \%$ saline to an inoculum density of $5 \times 10^{5} \mathrm{cfu} / \mathrm{mL}$ by comparison with a MacFarland standard. Tetracycline and oxacillin were dissolved directly in MHB, whereas norfloxacin and erythromycin 
were dissolved in DMSO and then diluted in MHB to give a starting concentration of $512 \mu \mathrm{g} / \mathrm{mL}$. Using Nunc 96-well microtitre plates, $125 \mu \mathrm{L}$ of MHB were dispensed into wells $1-11.125 \mu \mathrm{L}$ of the test compound or the appropriate antibiotic were dispensed into well 1 and serially diluted across the plate leaving well 11 empty for the growth control. The final volume was dispensed into well 12, which being free of MHB or inoculum served as the sterile control. Finally, the bacterial inoculum (125 $\mu \mathrm{L}$ ) was added to wells $1-11$ and the plate was incubated at $37^{\circ} \mathrm{C}$ for 18 hours. A DMSO control (3.125\%) was also included. All MICs were determined in duplicate. The MIC was determined as the lowest concentration at which no growth was observed. A methanolic solution $(5 \mathrm{mg} / \mathrm{mL})$ of 3-[4,5-dimethylthiazol-2-yl]-2,5diphenyl tetrazolium bromide (MTT; Lancaster) was used to detect bacterial growth by a colour change from yellow to blue [8].

\section{Results and discussion}

The HREIMS of 1 showed an [M+Na] peak at $\mathrm{m} / \mathrm{z} 331.1157$ (calc. 331.1163) and thereby, established its molecular formula as $\mathrm{C}_{16} \mathrm{H}_{20} \mathrm{O}_{6}$. The ${ }^{13} \mathrm{C}$ and DEPT135 NMR experiments revealed the presence of 16 carbons; three methyls (15.2, 21.3 and 21.4), one methylene (29.9), three carbonyls (164.0, 170.3 and 170.6) and nine methines, three of which were oxygenated. The ${ }^{1} \mathrm{H}$ NMR spectrum $\left(500 \mathrm{MHz}, \mathrm{CDCl}_{3}\right.$, Table 1) of 1 showed two acetoxy methyl groups which resonated at $2.06(3 \mathrm{H}, \mathrm{s})$ and $2.09(3 \mathrm{H}$, s) and a further $3 \mathrm{H}$ signal at $1.22(3 \mathrm{H}, \mathrm{d}, J=6.5 \mathrm{~Hz})$ which was attributable to a terminal secondary methyl group. The spectrum also exhibited two olefinic protons of a dihydropyrone skeleton [9] at $6.09(\mathrm{dq}, J=10.0,1.0 \mathrm{~Hz})$ and $6.92(\mathrm{ddd}, J=10.0$, 5.5, 3.0 Hz), two cis olefinic protons $(5.64, \mathrm{dd}, J=10.5,9.0 \mathrm{~Hz} ; 6.18, \mathrm{dd}, J=11.5$, $10.5 \mathrm{~Hz})$ and two trans olefinic protons $(6.52, \mathrm{dd}, J=15.0,11.5 \mathrm{~Hz} ; 5.77, \mathrm{dd}, J=$ 15.0, 7.0 Hz), one methylene $(2.44, \mathrm{~m})$ and three oxy-methines $(5.08,5.37$ and 5.45). 
The unambiguous assignment of all carbons and protons of $\mathbf{1}$ was achieved by a series of 2D experiments including HMQC, HMBC, COSY and NOESY. In the HMBC experiment, the proton at $6.92(\mathrm{H}-4)$ showed ${ }^{3} J$ connectivity to a carbonyl at $164.0(\mathrm{C}$ 2 ), and to an oxygenated methine carbon at $74.0\left(\mathrm{C}-6 ; \delta_{\mathrm{H}} 5.37\right.$ from HMQC). In the COSY experiment, H-4 revealed an expected interaction with H-3 $\left(\delta_{\mathrm{H}} 6.09 ; \delta_{\mathrm{C}} 121.9\right)$ and $\mathrm{H}_{2}-5\left(2.44 ; \delta_{\mathrm{C}} 29.9\right.$ from HMQC). These chemical shifts and their correlations supported the presence of 5,6-dihydro-2H-pyran-2-one as a part of the molecule. The olefinic proton at $5.64\left(\mathrm{H}-1\right.$ '; $\delta_{\mathrm{C}} 128.8$ from HMQC) coupled to H-6 and H-2' $\left(\delta_{\mathrm{H}}\right.$ $\left.6.18 ; \delta_{\mathrm{C}} 131.4\right)$ in the COSY experiment and showed ${ }^{3} J$ HMBC connectivity to a methylene carbon at $29.9(\mathrm{C}-5)$ and to an olefinic carbon at $128.4\left(\mathrm{C}-3^{\prime} ; \delta_{\mathrm{H}} 6.52\right)$. The latter proton $\left(\mathrm{H}-3^{\prime}\right)$ coupled to $\mathrm{H}-2^{\prime}$ and $\mathrm{H}-4^{\prime}\left(\delta_{\mathrm{H}} 5.77 ; \delta_{\mathrm{C}} 130.6\right)$ in the COSY experiment and exhibited a ${ }^{3} J$ HMBC correlation to $\mathrm{C}-1^{\prime}$ and to an oxygenated methine $74.8\left(\mathrm{C}^{-5}\right)$. The remaining oxy-methine proton at $5.08\left(\mathrm{H}-6^{\prime}\right)$ revealed a COSY interaction with $\mathrm{H}^{-5}$ ' and to a methyl doublet $(J=6.5 \mathrm{~Hz})$ at $1.22\left(\mathrm{H}_{3}-7^{\prime}\right.$; $\delta_{\mathrm{C}} 15.2$ from HMQC). The remaining methyls at 2.06 and 2.09 ppm showed ${ }^{2} J$ HMBC connectivity to their respective acetyl carbonyl carbons at 170.3 and 170.6 . The ${ }^{3} J$ HMBC correlation by H-5' and H-6' to the carbonyls at 170.6 and 170.3 confirmed their connectivity via $\mathrm{C}-5^{\prime}$ and $\mathrm{C}-6$ ', respectively. Accordingly, compound $\mathbf{1}$ was therefore identified as $6 \zeta-[5 \zeta, 6 \zeta$-diacetyloxy-1Z,3E-heptadienyl]-5,6-dihydro- $2 \mathrm{H}$ pyran-2one (1, Fig 1; named neohyptolide) which is a new compound. Because of paucity of the compound, it was not possible to carry out further study to confirm the absolute stereochemistry of the compound. However, $R$-configuration was proposed at C-5 by comparing its ${ }^{1} \mathrm{H}$ NMR data to other structurally related hyptolides $[9,10]$. Again, in view of the similarity of the coupling constants of the side chain protons at C-5' and C-6' of 1 to hyptolides reported from Hyptis oblongifolia [9] and 
pectinolides from Hyptis pectinata [11], the configurations of these chiral centers of $\mathbf{1}$ were assumed to be the same as in those compounds, i.e., $R$-configuration at $\mathrm{C}-5$ ' and $S$-configuration at C-6'. So taking these configurations into account, compound 1 was considered to be $6 R$-[5R,6S-diacetyloxy-1Z,3E-heptadienyl]-5,6-dihydro-2H-pyran2one.

By direct comparison of spectral data to those published in the literature, compounds 2-7 were identified as $\alpha$-himachalene (2) [12], 4-deacetoxy-10-epiolguine (3) [9], isoneocembrene-A (4) [13], $\beta$-caryophyllene oxide (5) [14], 3,5dihydroxy-7,4'-dimethoxyflavone (6) [15], 5-hydroxy-3,7,4'-trimethoxyflavone (7) $[15]$.

All compounds (1-7) were assessed for anti-staphylococcal activity in a minimum inhibitory concentration (MIC) assay but displayed only weak to moderate activity (Table 2). Among the compounds, the comparatively better antistaphylococcal activity was exhibited by compound 1. $\alpha$-Pyrones with structural similarity to $\mathbf{1}$ have been reported to exhibit antibacterial properties including those against the clinical isolates of Staphylococcal aureus [16]. The cytotoxic potential of pectinolides was also reported with a number of cultured cell lines [16]. It is suggested that the presence of an alpha-beta unsaturated ketone, which is part of the lactone moiety may make this compound a substrate for biological nucleophiles and it is likely that this compound is also cytotoxic to mammalian cells as is seen in the case of the pectinolides [16].

\section{Acknowledgement}

MMR is grateful to the Leverhulme Trust for the award of postdoctoral research fellowship (DD-LF). 


\section{References}

[1] Hutchinson J, Dalziel JM. Flora of West Tropical Africa: Vol. 2 EricaceaeLabiatae, 2nd edition, London: Crown Agents; 1963.

[2] Gibbons S, Oluwatuyi M, Veitch NC, Gray AI. Bacterial resistance modifying agents from Lycopus europaeus. Phytochemistry 2003;62:83-87.

[3] Stavri M, Gibbons S. Antibacterial constituents from Plectranthus ciliatus. Planta Med 2007;73:873.

[4] Gibbons S, Udo EE. The effect of reserpine, a modulator of multidrug efflux pumps, on the in vitro activity of tetracycline against clinical isolates of methicillin-resistant Staphylococcus aureus (MRSA) possessing the tet(K) determinant. Phytother Res 2000;14:139-140.

[5] Richardson JF, Reith S. Characterization of a strain of methicillin-resistant Staphylococcus aureus (EMRSA-15) by conventional and molecular methods. J Hosp Infect 1993;25:45-52.

[6] Ross JI, Farrell AM, Eady EA, Cove JH, Cunliffe WJ. Characterisation and molecular cloning of the novel macrolidestreptogramin B resistance determinant from Staphylococcus epidermidis. J Antimicrob Chemother 1989;24:851-862.

[7] Kaatz GW, Seo SM, Ruble CA. Efflux-mediated fluoroquinolone resistance in Staphylococcus aureus. Antimicrob. Agents Chemother 1993;37:1086-1094.

[8] Rahman MM, Garvey M, Piddock L, Gibbons S. Antibacterial terpenes from the oleo-resin of Commiphora molmol (Engl.). Phytother Res 2008;22:1356-1360.

[9] Pereda-Miranda R, Garcia M, Delgado G. Structure and stereochemistry of four $\alpha$ pyrones from Hyptis oblongifolia. Phytochemistry 1990;29:2971-2974. 
[10] Achmad S, Hoyer T, Kjaer A, Makmur L, Norrestam R. Molecular and crystal structure of hyptolide, a naturally occurring unsaturated lactone. Acta Chem. Stand. 1987; B 41: 599.

[11] Boalino DM, Connolly JD, McLean S, Reynolds, WF, Tinto, WF. $\alpha$-Pyrones and a 2(5H)-furanone from Hyptis pectinata. Phytochemistry 2003;64:1303-1307.

[12] Bartelt, R. J., Cosse' , A. A., Zilkowski, B. W., Weisleder, D., and Momany, F. A. 2001. Malespecific sesquiterpenes from Phyllotreta and Aphthona flea beetles J. Chem. Ecol. 27: 2397- 2423

[13] Birch AJ, Brown WV, Corrie JET, Moore BP. Neocembrene-a, a termite trail pheromone. J. Chem. Soc. Perkin Trans 1972;1:2653.

[14] Rahman MM. Phytochemical and antimicrobial studies on some species of Bangladeshi Leguminosae and Rutaceae [ $\mathrm{PhD}$ Thesis]. University of Strathclyde; 2002.

[15] Rossi MH, Yoshida M, Maia JGS. Neolignans, styrylpyrones and flavonoids from an Aniba species. Phytochemistry 1997; 45:1263-1269.

[16] Pereda-Miranda R, Hernandez L, Villavicencio J, Novelo M, Ibarra P. Structure and stereochemistry of pentinolides A-C, novel antimicrobial and cytotoxic 5,6dihydro- $\alpha$-pyrones from Hyptis pectinata. J. Nat. Prod. 1993;56:583-593. 
Table 1

${ }^{1} \mathrm{H}$ NMR $(500 \mathrm{MHz}),{ }^{13} \mathrm{C} \mathrm{NMR}(125 \mathrm{MHz})$ and $\mathrm{HMBC}$ data of 1 in $\mathrm{CDCl}_{3}$

\begin{tabular}{|c|c|c|c|c|}
\hline \multirow[t]{2}{*}{ Position } & \multirow[t]{2}{*}{${ }^{1} \mathrm{H}$} & \multirow[t]{2}{*}{${ }^{13} \mathrm{C}$} & \multicolumn{2}{|l|}{$\mathrm{HMBC}$} \\
\hline & & & ${ }^{2} J$ & ${ }^{3} J$ \\
\hline 2 & - & 164.0 & - & - \\
\hline 3 & $6.09, \mathrm{dq}, J=10.0,1.0 \mathrm{~Hz}$ & 121.9 & $\mathrm{C}-2, \mathrm{C}-4$ & $\mathrm{C}-5$ \\
\hline 4 & $6.92, \mathrm{ddd}, J=10.0,5.5,3.0 \mathrm{~Hz}$ & 144.8 & $\mathrm{C}-3$ & $\mathrm{C}-2, \mathrm{C}-6$ \\
\hline 5 & $2.44, \mathrm{~m}$ & 29.9 & $\mathrm{C}-4$ & $\mathrm{C}-3, \mathrm{C}-1^{\prime}$ \\
\hline 6 & $5.37, \mathrm{ddt}, J=10.0,5.0,1.0 \mathrm{~Hz}$ & 74.0 & - & $\mathrm{C}-4, \mathrm{C}-2^{\prime}$ \\
\hline $1^{\prime}$ & $5.64, \mathrm{dd}, J=10.5,9.0 \mathrm{~Hz}$ & 128.8 & $\mathrm{C}-2^{\prime}$ & $\mathrm{C}-5, \mathrm{C}-3^{\prime}$ \\
\hline $2^{\prime}$ & $6.18, \mathrm{dd}, J=11.5,10.5 \mathrm{~Hz}$ & 131.4 & $\mathrm{C}-1^{\prime}, \mathrm{C}-3^{\prime}$ & $\mathrm{C}-6, \mathrm{C}-4^{\prime}$ \\
\hline $3^{\prime}$ & $6.52, \mathrm{dd}, J=15.0,11.5 \mathrm{~Hz}$ & 128.4 & $\mathrm{C}-2^{\prime}, \mathrm{C}-4^{\prime}$ & $\mathrm{C}-1^{\prime}, \mathrm{C}-5^{\prime}$ \\
\hline $4^{\prime}$ & $5.77, \mathrm{dd}, J=15.0,7.0 \mathrm{~Hz}$ & 130.6 & $C-3 ',-5^{\prime}$ & $C-4^{\prime},-6^{\prime}$ \\
\hline $5^{\prime}$ & $5.45, \mathrm{ddd}, J=7.0,3.5,1.0 \mathrm{~Hz}$ & 74.8 & C-6' & $C-3 ',-7^{\prime}$ \\
\hline $6^{\prime}$ & $5.08, \mathrm{dq}, J=6.5,3.5 \mathrm{~Hz}$ & 70.7 & $C-5^{\prime}$ & C-4' \\
\hline $7^{\prime}$ & $1.22, \mathrm{~d}, J=6.5 \mathrm{~Hz}$ & 15.2 & C-6' & $C-5^{\prime}$ \\
\hline$\underline{\mathrm{CH}}_{3} \mathrm{CO}-5^{\prime}$ & $2.09, \mathrm{~s}$ & 21.3 & $\mathrm{CO}-5^{\prime}$ & - \\
\hline$\underline{\mathrm{CH}}_{3}{ }^{\mathrm{CO}} \mathrm{CO}-6^{\prime}$ & $2.06, \mathrm{~s}$ & 21.4 & $\mathrm{CO}-6^{\prime}$ & - \\
\hline $\mathrm{CH}_{3} \underline{\mathrm{CO}}-5^{\prime}$ & - & 170.6 & - & - \\
\hline $\mathrm{CH}_{3} \underline{\mathrm{CO}}-6^{\prime}$ & - & 170.3 & - & - \\
\hline
\end{tabular}


Table 2

Minimum Inhibitory Concentrations $(\mu \mathrm{g} / \mathrm{mL})$ of compounds 1-7 against clinical isolates of multi-drug resistant (MDR) and methicillin-resistant strains of Staphylococcus aureus.

\begin{tabular}{llllll}
\hline Compounds & SA1199B & RN4220 & EMRSA-15 & XU-212 & ATCC25923 \\
\hline $\mathbf{1}$ & 64 & 64 & 64 & 64 & 128 \\
$\mathbf{2}$ & 64 & 64 & 128 & 64 & 128 \\
$\mathbf{3}$ & 64 & 128 & 64 & 128 & 128 \\
$\mathbf{4}$ & 64 & 128 & 128 & 64 & 128 \\
$\mathbf{5}$ & 256 & 256 & 256 & 128 & 128 \\
$\mathbf{6}$ & 256 & 128 & 128 & 128 & 128 \\
$\mathbf{7}$ & 256 & 256 & 256 & 128 & 256 \\
Norfloxacin & 32 & 2 & 1 & 16 & 1 \\
\hline
\end{tabular}



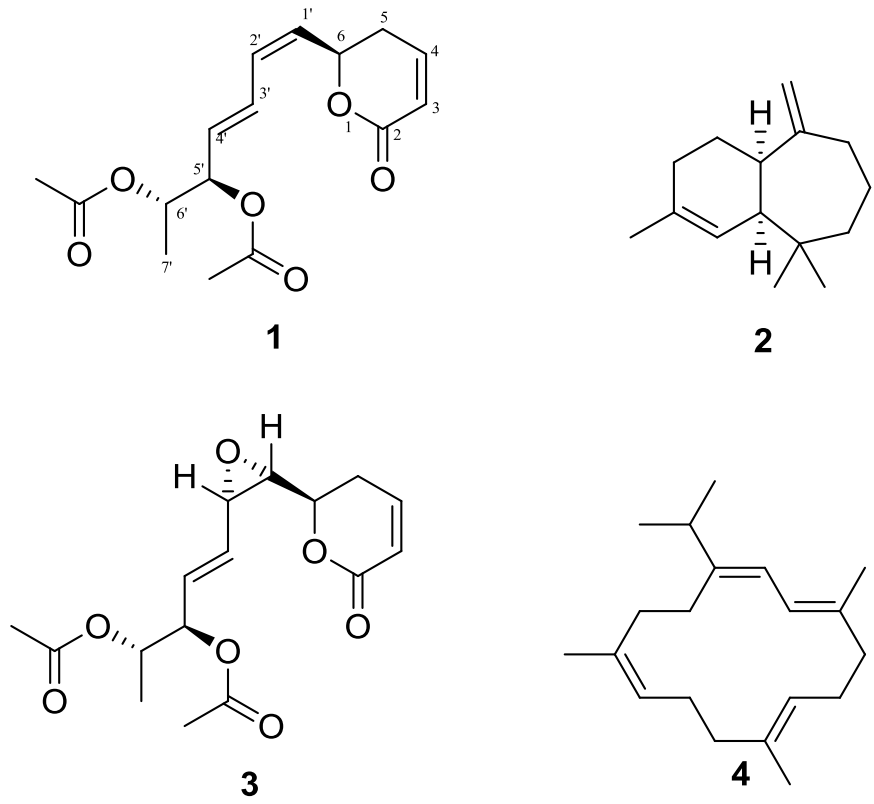

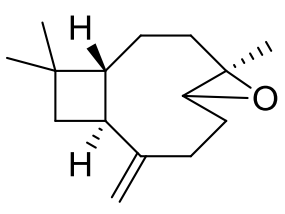

5<smiles>[R]Oc1c(-c2ccc(OC)cc2)oc2cc(OC)cc(O)c2c1=O</smiles>

6; $\mathrm{R}=\mathrm{H}$ 7; $\mathrm{R}=\mathrm{Me}$

Fig 1. Structures of compound 1-7 